\title{
Heavy Metal Accumulation Potential of Some Wetland Plants Growing Naturally in the City of Kolkata, India
}

\author{
Poulami Jha1, Alok C. Samal' ${ }^{2}$, Subhash C. Santra ${ }^{2}$, Anjana Dewanji ${ }^{*}$ \\ ${ }^{1}$ Agricultural and Ecological Research Unit, Indian Statistical Institute, Kolkata, India \\ ${ }^{2}$ Department of Environmental Science, University of Kalyani, Kalyani, India \\ Email:*anjdew@gmail.com
}

How to cite this paper: Jha, P., Samal, A.C., Santra, S.C. and Dewanji, A. (2016) Heavy Metal Accumulation Potential of Some Wetland Plants Growing Naturally in the City of Kolkata, India. American Journal of Plant Sciences, 7, 2112-2137. http://dx.doi.org/10.4236/ajps.2016.715189

Received: August 26, 2016

Accepted: October 25, 2016

Published: October 28, 2016

Copyright $\odot 2016$ by authors and Scientific Research Publishing Inc. This work is licensed under the Creative Commons Attribution International License (CC BY 4.0).

http://creativecommons.org/licenses/by/4.0/

\section{Abstract}

Freshwaters are not only used locally in many developing countries but they are often over exploited for domestic purposes, agriculture and disposal of industrial wastes which result in an overload of excess nutrients, harmful chemicals and heavy metals. Plant species together with sediments and water samples collected from eleven aquatic water bodies in the vicinity of industrial units in Kolkata were studied for their potential to uptake $\mathrm{Pb}, \mathrm{Cd}$ and $\mathrm{Cr}$ under field conditions. $\mathrm{Cd}$ and $\mathrm{Cr}$ concentrations in the sediments were higher than background values considered to be toxic. Alternanthera philoxeroides and Eichhornia crassipes were the two invasive species present, with the former being more widely distributed. Among native plants, Ipomoea aquatica was the most abundant. Metal uptake in the plants differed among species, tissues and sites. $\mathrm{Pb}$ and $\mathrm{Cd}$ accumulation in root tissues for all plants in most sites suggested an exclusion strategy for metal tolerance. Since I. aquatica is widely consumed in many parts of SE Asia, its metal content should be checked before use since it was found to efficiently translocate both $\mathrm{Pb}$ and $\mathrm{Cd}$ from roots to shoots. The potential of $A$. philoxeroides as a metal excluder needs to be explored further since it translocates less to its shoots as compared to E. crassipes and I. aquatica.

\section{Keywords}

Alternanthera philoxeroides, Eichhornia crassipes, Invasive, Ipomoea aquatica, Lead $(\mathrm{Pb})$, Cadmium $(\mathrm{Cd})$, Chromium $(\mathrm{Cr})$

\section{Introduction}

Rapid urbanization and industrialization are occurring in many parts of the world. 
Human activities such as mining, landfill leachates, industrial emissions, vehicular emissions, fossil fuels, fertilizer erosion from agricultural run-off, herbicides and pesticides, sewage and municipal wastes all contribute to the accumulation of pollutants in nearby aquatic systems [1] [2], which are thought to be a safe site for disposal of polluted sediments [3]. Among the worst environmental contaminants are the heavy metals which are elements with atomic number $>20$, specific density $>5 \mathrm{gm} / \mathrm{cm}^{3}$ and relative atomic mass above 40 [4] [5]. Pb ranks second, $\mathrm{Cd}$ seventh and hexavalent $\mathrm{Cr}$ ranks seventeen based on frequency, toxicity and potential for human exposure according to the Priority List of Hazardous Substances, U.S. Department of Health \& Human Services [ATSDR, website: http://www.atsdr.cdc.gov/spl/]. Beside arsenic and mercury, these are the only three heavy metals among the top twenty in this list. These metals gradually accumulate in some plants and animals and can interfere with normal human metabolic activity when taken in through the food chain [6]. These elements, which are non-essential and phytotoxic both at low as well as very high concentrations, are commonly detected in wastewaters and can be critical because of their persistence in the environment. Their accumulation in the sediments and subsequent transfer from soil/sediments to plants is thus of great concern [7].

Freshwater ecosystems, which have greater biodiversity per surface area, are subject to more anthropogenic impacts compared to terrestrial or marine ecosystem [8] [9]. As one of the main biological components of freshwater systems, aquatic plants or macrophytes not only assimilate pollutants directly into their tissues, but can also act as catalysts for purification reactions by increasing environmental diversity in the rhizosphere, thereby promoting various chemical and biochemical reactions that enhance purification [10]. These plants are also important since they are a source of oxygen, provide food, shade and cover for fish and other aquatic organisms. However, freshwater ecosystems seem to be at particular risk from invasive plant species because of threats to biodiversity [11] and human needs for water resources [12]. In India too, many aquatic bodies including rivers, lakes, ponds and canals are now fully covered by excessive growth of invasive plants [13], which if left unchecked become extremely difficult to control. Thus, together with other plants, invasive aquatic macrophytes appear to be a good choice for metal accumulation studies since they can grow rapidly, are tolerant to harsh conditions, produce sufficient biomass and are easy to harvest [14].

The use of aquatic plants for heavy metal removal has been extensively reviewed [5] [6] [15]-[17] and widely studied both under laboratory [18]-[20] as well as field conditions [21]-[27]. Insights from all these studies point to the existence of a wide variation in the ability of different plants to accumulate heavy metals and the ability of a particular genera or species to accumulate different amounts of the same heavy metal from different sites. This variability depends upon environmental factors like metal speciation of the sediment, initial concentration of the metal present at a particular site, $\mathrm{pH}$, redox potential, sediment organic matter, interaction of different heavy metals among each other and the plant growth form [28]-[30]. Moreover, the concentration of heavy metals in the root tissues of freshwater macrophytes from polluted areas has been 
found to be higher compared to that of their aboveground parts [15] [21] [22]. Due to this great variability in the ability of plant species to accumulate and translocate metals, the potential of regionally abundant plant species, well adapted to local climatic and edaphic conditions, should be explored in view of the plethora of contaminated urban sites around the world which pose risk to humans and other organisms. This study was, therefore, formulated to throw some light on the total concentration of selected heavy metals $(\mathrm{Pb}, \mathrm{Cd}$ and $\mathrm{Cr})$ in water, sediments and plants growing in contaminated sites in the metropolitan city of Kolkata in India. The uptake of the three metals was determined in the root and shoot tissues of the plants present at each site and the metal accumulation into the plant parts was calculated to assess their bioaccumulation potential.

\section{Materials and Methods}

\subsection{Study Area and Sites}

Contaminated sites along canals and ponds with direct discharge of raw industrial effluents, untreated sewage and wastewater from commercial, industrial and domestic establishments were extensively surveyed in and around the metropolitan city of Kolkata, India. Eleven accessible sites with presence of plant species were finally selected for the study. A global positioning system (GPS) was used for recording the coordinates of the sites chosen for sampling. Table 1 gives the location of the study sites with their probable source of contamination and the number of plant species present in them.

\subsection{Sample Collection and Analysis}

At each site, a quadrat of size $0.5 \times 0.5 \mathrm{~m}^{2}$ was floated on stands of vegetation present at

Table 1. Location of study sites.

\begin{tabular}{|c|c|c|c|c|c|c|c|}
\hline $\begin{array}{c}\text { Site } \\
\text { number }\end{array}$ & Location & $\begin{array}{l}\text { Latitude } \\
(\mathrm{N})\end{array}$ & $\begin{array}{l}\text { Longitude } \\
\text { (E) }\end{array}$ & $\begin{array}{c}\text { Waterbody } \\
\text { type }\end{array}$ & Probable source of contamination & \multicolumn{2}{|c|}{ Number of plant species present } \\
\hline 1 & Chowbaga & $22^{\circ} 31^{\prime} 15.4^{\prime \prime}$ & $88^{\circ} 25^{\prime} 15.0^{\prime \prime}$ & Pond & Tannery effluents & 2 & 2 \\
\hline 2 & Sodepur & $22^{\circ} 43^{\prime} 01.7^{\prime \prime}$ & $88^{\circ} 23^{\prime} 36.8^{\prime \prime}$ & Canal & Domestic waste & 2 & 1 \\
\hline 3 & Dunlop & $22^{\circ} 38^{\prime} 58.3^{\prime \prime}$ & $88^{\circ} 22^{\prime} 36.9^{\prime \prime}$ & Pond & Vehicular emission and construction & 1 & 1 \\
\hline 5 & Old Delhi road & $22^{\circ} 43^{\prime} 59.7^{\prime \prime}$ & $88^{\circ} 18^{\prime} 51.2^{\prime \prime}$ & Canal & Iron industry & 1 & 3 \\
\hline 6 & Bighati & $22^{\circ} 48^{\prime} 25.7^{\prime \prime}$ & $88^{\circ} 18^{\prime} 53.4^{\prime \prime}$ & Pond & Logs products industry & 1 & 1 \\
\hline 7 & Satragachi & $22^{\circ} 35^{\prime} 18.9^{\prime \prime}$ & $88^{\circ} 15^{\prime} 56.6^{\prime \prime}$ & Pond & Domestic waste dumping ground & 2 & 1 \\
\hline 10 & Nilganj & $22^{\circ} 44^{\prime} 53.9^{\prime \prime}$ & $88^{\circ} 25^{\prime} 17.8^{\prime \prime}$ & Canal & Brick industry & 1 & 2 \\
\hline 11 & Anandapur & $22^{\circ} 30^{\prime} 26.8^{\prime \prime}$ & $88^{\circ} 24^{\prime} 16.3^{\prime \prime}$ & Canal & Slum waste & 1 & 2 \\
\hline
\end{tabular}


the junction of the littoral slope and the water body. Species with adequate growth to cover the quadrat area were sampled along with contiguous sediments. Sparsely present species were not considered for the study. Samples collected for each plant species were labeled, put in individual polythene bags and brought to the laboratory. The plant samples were separated into root and shoot portions and thoroughly washed with distilled water to remove all adhering soil and dirt particles. Fresh weight of root and shoot were recorded for all plants. Samples were then oven dried to constant weight at $70^{\circ} \mathrm{C}$ for 72 hours and dry weights recorded. Each dried sample was ground to powder using a Cyclotec Mill (Model 1093 sample mill, Tecator) and stored for subsequent analysis. The labeled sediment samples were brought to the laboratory, air dried to constant weight, ground into a fine powder using a mortar and pestle and sieved through a 2 mm mesh. Water samples from each site were collected using a Van Dorn sampler and on-site measurements for $\mathrm{pH}$ and conductivity were done using hand held probes (pHTestr 30, Eutech Instruments; ECTestr11+, Eutech Instruments). A $250 \mathrm{ml}$ bottle and three 1 litre bottles were filled separately, preserved with $2 \mathrm{~mL}$ concentrated $\mathrm{HNO}_{3}$ and brought to the laboratory under ice for other water quality and heavy metal analysis.

Turbidity was measured in the laboratory using a turbidimeter (Model 2100P, HACH Company, USA) while total dissolved and suspended solids in the water samples were measured using standard methods [31]. For heavy metal analysis, water samples (1 litre) were initially evaporated to dryness while sediments $(1 \mathrm{~g})$ and plant parts (shoots: $1 \mathrm{~g}$; roots: $0.5 \mathrm{~g}$ ) were directly digested with nitric and perchloric acid till a clear solution was obtained and then diluted to $50 \mathrm{~mL}$ with double distilled water [31] [32]. $\mathrm{Pb}, \mathrm{Cd}$ and $\mathrm{Cr}$ were analyzed by direct aspiration of the sample solution into a Perkin-Elmer Analyst-400 Atomic Absorption Spectrophotometer following the method of Nayek et al., [24]. Below detection limit for $\mathrm{Pb}, \mathrm{Cd}$ and $\mathrm{Cr}$ were $0.015 \mathrm{ppm}$, $0.008 \mathrm{ppm}$ and $0.003 \mathrm{ppm}$ respectively.

In order to estimate a plant's potential for phytoremediation purpose, bioaccumulation factor for shoot (BAFs) and root (BAFr) together with translocation factor (TF) were determined from the metal content in the sediments and plant parts as follows:

Bio-accumulation Factor $(\mathrm{BAFs})=$ metal concentration in shoot $/$ metal concentration in sediment.

Bio-accumulation Factor $(\mathrm{BAFr})=$ metal concentration in root $/$ metal concentration in sediment.

Translocation factor $(\mathrm{TF})=$ metal concentration in shoot $/$ metal concentration in root.

Bio-accumulation Factor (BAF) is used to quantify the toxic element accumulation efficiency in plants by comparing the concentration in the plant part and an external medium [33]. BAF has been categorised as: $<1$ excluder, $1-10$ accumulator and $>10$ hyperaccumulator [34]. A plant's ability to translocate metals from the roots to the shoots is measured using the TF [33] and TF $>1$ signifies that the plant effectively translocates heavy metals from roots to the shoots [35]. 


\section{Results and Discussion}

\subsection{Plant Species and Dry Weights}

The plants which satisfied the "adequate growth" criterion, within each quadrat, at their sites of occurrence were Alternanthera philoxeroides, Commelina benghalensis, Eichhornia crassipes, Enhydra fluctuans, Ipomoea aquatica, Ludwigia adscendens, Sagittaria sagittifolia and the sedges. Among these, A. philoxeroides (alligator weed) and E. crassipes (water hyacinth) were the only two invasive species while the rest were native plants. While A. philoxeroides was present in all sites, E. crassipes occurred in 5 sites. Ipomoea aquatica (water spinach), the most commonly occurring native species, was present in 6 sites. It is interesting to note the complete absence of native species from Sites 8 and 9 (both sewage canal sites, Table 1) while invasive species (at least one or both) were present in all sites, irrespective of water body type. The widespread occurrence of both $A$. philoxeroides and E. crassipes in the warm waters of the tropics has been widely reported together with their negative impacts on biodiversity [36]-[38].

The overall shoot dry matter content in the plants studied ranged from $7.07 \%$ $12.28 \%$ in $A$. philoxeroides $(\mathrm{n}=11), 4.98 \%-6.85 \%$ in E. crassipes $(\mathrm{n}=5), 7.40 \%$ $8.25 \%$ in $I$. aquatica $(\mathrm{n}=6), 14.20 \%-16.41 \%$ in the sedges $(\mathrm{n}=3), 8.30 \%-8.52 \%$ in $C$. benghalensis $(\mathrm{n}=2), 5.55 \%-6.12 \%$ in $S$. sagittifolia $(\mathrm{n}=2), 4.42 \%$ in E. flutuans $(\mathrm{n}=$ 1 ) and $12.91 \%$ in $L$. adscendens $(\mathrm{n}=1)$. In case of roots, dry matter values ranged from $6.33 \%-11.22 \%$ in $A$. philoxeroides, $5.40 \%-6.64 \%$ in E. crassipes, $7.25 \%-9.80 \%$ in $I$. aquatica, $14.04 \%-14.75 \%$ in the sedges, $8.00 \%-8.33 \%$ in C. benghalensis, $7.25 \%$ $8.37 \%$ in $S$. sagittifolia, $4.67 \%$ in E. flutuans and $6.67 \%$ in L. adscendens. E. fluctuans had lowest dry matter content for both shoot and root while the sedges showed highest dry matter content for both shoot (16.41\% in site 11$)$ and root (14.75\% in site 5) among all the plants. Among sites, minimum variation in dry matter content of both shoot and root was observed in $C$. benghalensis while maximum variation was observed in $A$. philoxeroides.

\subsection{Water Quality}

The results of water quality analysis pertaining to the 11 sites are given in Table 2 . The $\mathrm{pH}$, which greatly affects mobility and bioavailability of metals [39], was $>8$ at Sites 6,8 and 10 but were generally within the prescribed limits (5.5 to 9.0) as described by the Central Pollution Control Board, India for discharge of environmental pollutants into inland surface waters (CPCB, http://www.cpcb.nic.in/GeneralStandards.pdf). Conductivity values, a measure of the dissolved salts present in water, were quite high $(>1000$ $\mu \mathrm{S}$ ) in most of the sites possibly due to elevated levels of total dissolved solids ( $\mathrm{r}=$ $0.904, \mathrm{p}$ value $<0.01$ ), which is known to influence conductivity [40] [41]. Turbidity varied widely between sites ranging from low values $(<20 \mathrm{NTU})$ in Sites 3 and 11 to a much higher value ( $>400 \mathrm{NTU}$ ) in Site 7 . The most turbid waterbody (Site 7) had suspended solid values $>300 \mathrm{mg} \cdot \mathrm{L}^{-1}$ which could be responsible for its decreased water transparency. A positive correlation $(\mathrm{r}=0.809, \mathrm{p}$ value $<0.01)$ between turbidity and suspended solids accounts for the linear relationship [42]. 
Table 2. Analysis of wastewater.

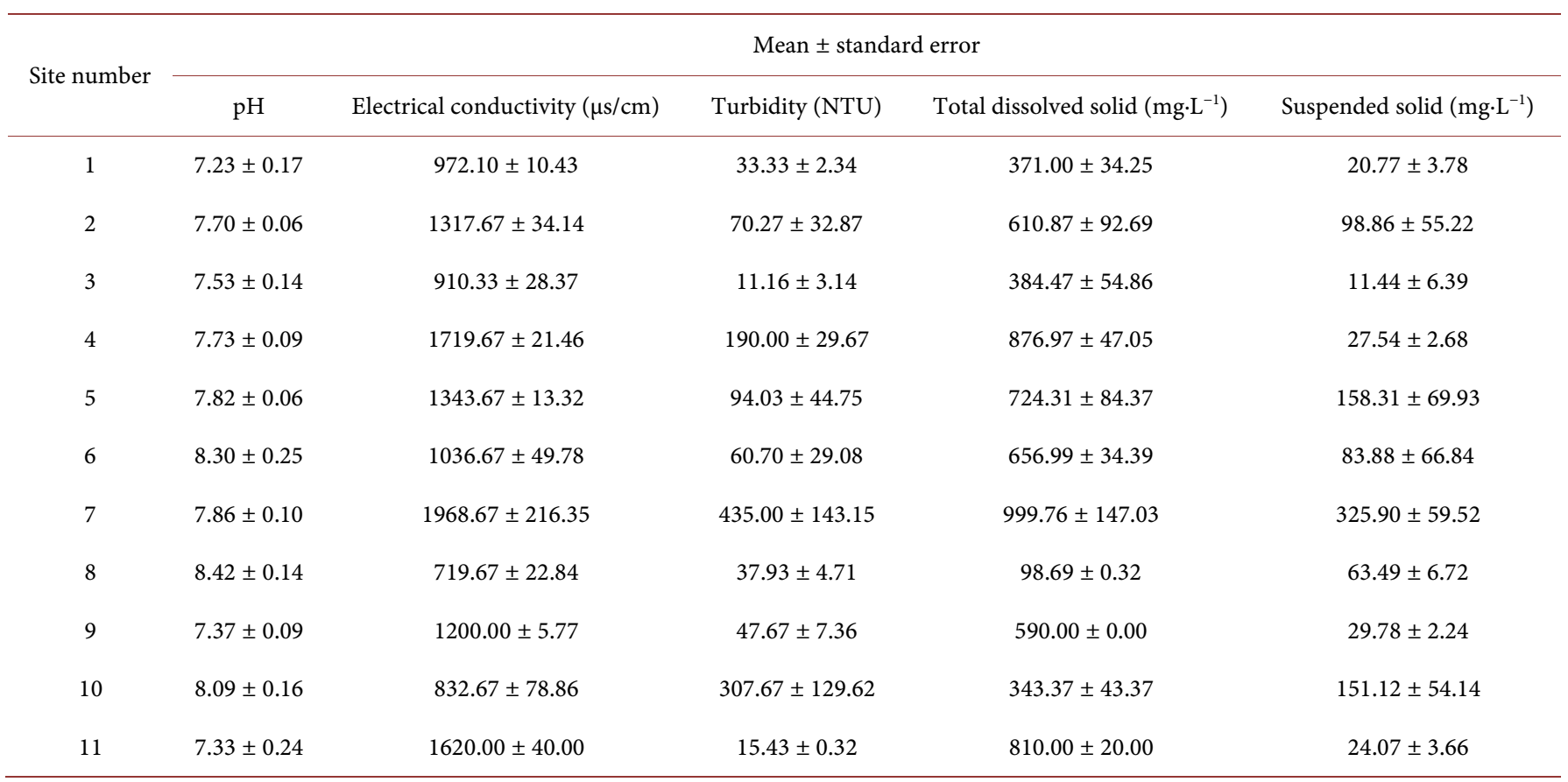

\subsection{Heavy Metals in Water}

$\mathrm{The} \mathrm{Pb}, \mathrm{Cd}$ and $\mathrm{Cr}$ content in the water collected from all 11 sites have been reported in Table 3.

The low concentrations of all the three metals were probably because the sites were not located at the pollution source and were subject to dilution effects. However, $\mathrm{Pb}$ $\left(0.022 \mathrm{mg} \cdot \mathrm{L}^{-1}\right)$ and $\mathrm{Cd}\left(0.032 \mathrm{mg} \cdot \mathrm{L}^{-1}\right)$ concentration in water was similar to those reported for an East Kolkata wetland site [43], while the $\mathrm{Cr}$ concentration $\left(3.6 \mathrm{mg} \cdot \mathrm{L}^{-1}\right.$ ) was low compared to that of a sewage fed fish pond in East Kolkata wetland [44]. All values were within the prescribed limits for metals ( $\mathrm{Pb}: 0.1 \mathrm{ppm}, \mathrm{Cd}$ and $\mathrm{Cr}: 2.0 \mathrm{ppm}$ ) as recommended by FAO water quality criteria for irrigational water and the Central Pollution Control Board, India for the discharge of environmental pollutants into inland surface waters [СРСB, http://www.cpcb.nic.in/GeneralStandards.pdf]. However, values for $\mathrm{Cd}$ were higher than the USEPA recommended values for aquatic life criteria.

Due to variation in water levels and a low resting time, analysis of water for estimation of heavy metals may not be conclusive [3]. The sediments derived from the settling of particulates from water itself could be more useful and confirmatory as residence time for contaminants are very high in the sediment [45]. Moreover, all the plants were collected from littoral areas and were mostly rooted to the bottom which could greatly influence metal uptake from the sediments rather than from the water. Sediments are dynamic bodies in equilibrium with environmental forces acting on them and chemical reactions induced by the roots of plants, in the sediments that they grow in, is also known to influence the sediment's capacity to uptake metals [46]. 
Table 3. Heavy metal concentration in wastewater.

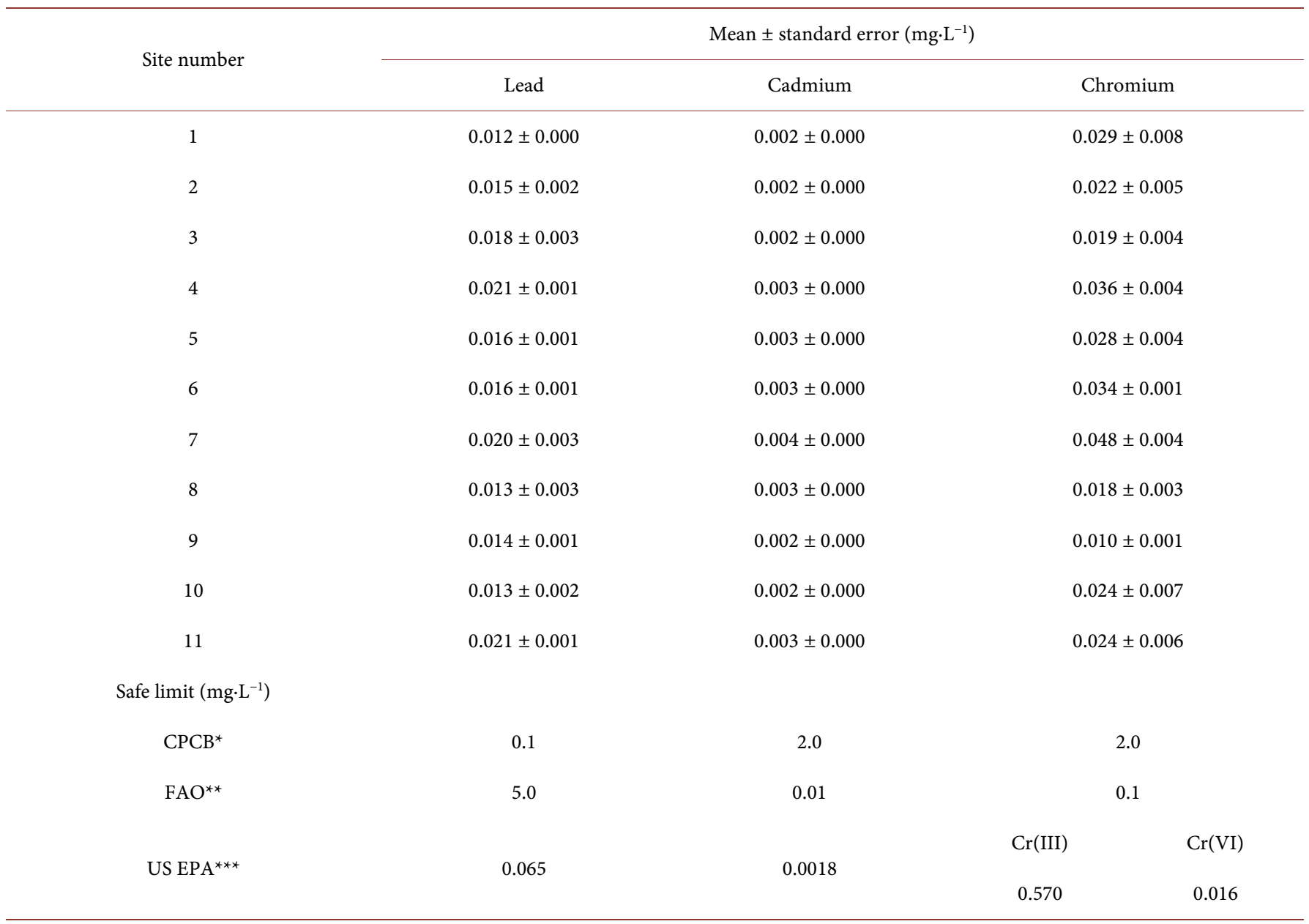

*Values provided by Central Pollution Control Board, India for discharge of environmental pollutants into the inland surface water. (Website: http://www.scpcb.nic.in/GeneralStandards.Pdf) ${ }^{* *}$ FAO water quality criteria for irrigational water (website: http://www.fao.org/docrep/t0551e/t0551e04.htm\#2.4 water quality guidelines for maximum crop production). ${ }^{* * *}$ EPA National recommended aquatic life criteria table (website: https://www.epa.gov/wqc/national-recommended-water-quality-criteria-aquatic-life-criteria-table).

\subsection{Heavy Metals in Sediments}

The heavy metal content of the sediments collected from the different sites are shown in Figures 1(a)-(c). The sediments were not polluted in terms of $\mathrm{Pb}$ (Figure 1(a)) since concentrations were below the background values of $70 \mathrm{mg} \cdot \mathrm{kg}^{-1}$ [47] [48]. Similar Pb concentrations have been reported from the sediments $\left(50.5 \mathrm{mg} \cdot \mathrm{kg}^{-1}\right)$ of an East Kolkata wetland [43]. Soil $\mathrm{Pb}$ levels in heavily polluted industrial areas of India ranged from 2 to $293 \mathrm{mg} \cdot \mathrm{kg}^{-1}$ [49] [50].

Cd concentration in the sediments for all sites (Figure 1(b)) were quite high compared to the background value of $1.0 \mathrm{ppm}$ [47] [48]. The highest Cd concentration was observed in the sediment from Site 1, which could be attributed to a tannery in the neighbourhood. The Cd concentration in the sediments from other sites were similar to values of $\mathrm{Cd}\left(10.1 \mathrm{mg} \cdot \mathrm{kg}^{-1}\right)$ reported for a Ramsar site [43]. Cr concentration (Figure 1(c)) was also particularly high in Site 1 and Site 6 . Tannery industry, where Cr salts are 
P. Jha et al.

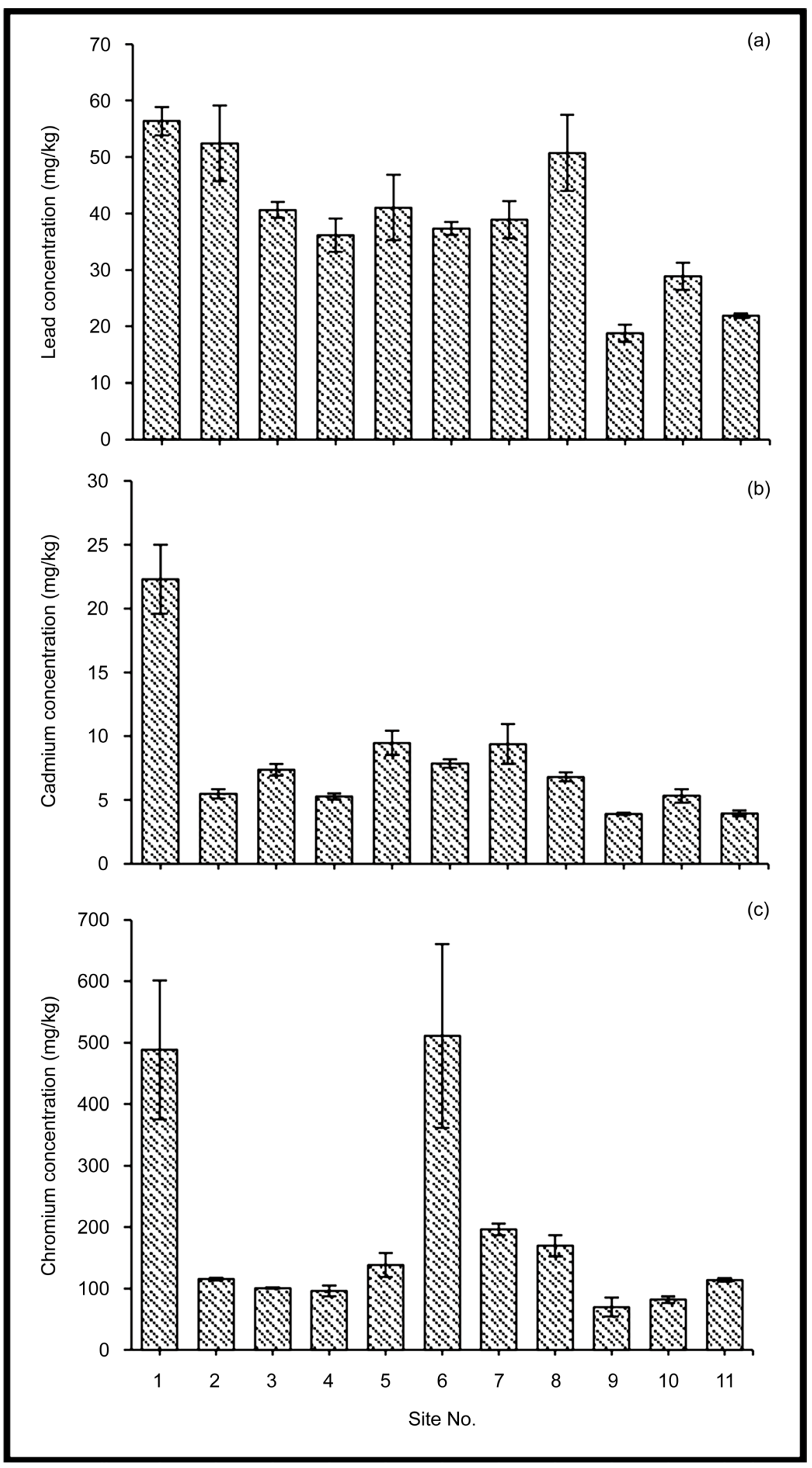

Figure 1. Concentrations of Lead (a), Cadmium (b) and Chromium (c) in the sediments across 11 sites. 
used for tanning leather products [51], is a large contributor of $\mathrm{Cr}$ pollution in India [52]. Chromated copper arsenate used as a wood preservative [53], could be probable reasons for the high $\mathrm{Cr}$ deposition in Site 6. Cr concentration was higher than the background value of $90 \mathrm{mg} \cdot \mathrm{kg}^{-1}$ [47] [48] for all sites except Sites 9 and 10.

\subsection{Heavy Metals in Plant Parts}

The overall $\mathrm{Pb}, \mathrm{Cd}$ and $\mathrm{Cr}$ contents in the above and below ground portions of the plants studied have been provided in Table 4 . It is clearly evident from the median values of each metal that the shoots and roots of individual plants accumulated metals in the order $\mathrm{Pb}>\mathrm{Cr}>\mathrm{Cd}$. All plants had greater than phytotoxic concentrations of both $\mathrm{Pb}\left(5.0 \mathrm{mg} \cdot \mathrm{kg}^{-1}\right)$ and $\mathrm{Cd}\left(0.5 \mathrm{mg} \cdot \mathrm{kg}^{-1}\right)$ in their shoots [24] [54]. All the plants harvested during this study were healthy and did not show any toxicity symptoms although excess $\mathrm{Pb}$ in plants is reported to inhibit growth while $\mathrm{Cd}$ can inhibit photosynthesis and mineral assimilation with leaf chlorosis, necrosis, and abscission [55] [56]. Minimum values of $\mathrm{Cr}$ for shoots of most plants were "below detection limit" while maximum uptake of $\mathrm{Cr}$ values in shoots were detected in both the invasive species (E. crassipes: $18.45 \mathrm{mg} \cdot \mathrm{kg}^{-1}$ and $A$. philoxeroides: $\left.15.32 \mathrm{mg} \cdot \mathrm{kg}^{-1}\right)$.

Maximum $\mathrm{Pb}$ concentrations $\left(>80 \mathrm{mg} \cdot \mathrm{kg}^{-1}\right.$ ) could be detected in roots of both invasive (A. philoxeroides and E. crassipes) and native plants ( $C$. benghalensis and sedges). The highest median $\mathrm{Pb}$ concentration was evident in the roots of $C$. benghalensis (76.4 $\mathrm{mg} \cdot \mathrm{kg}^{-1}$ ) while the lowest was present in $I$. aquatica $\left(42.18 \mathrm{mg} \cdot \mathrm{kg}^{-1}\right)$. The median $\mathrm{Cd}$ concentration in roots varied from $7.89 \mathrm{mg} \cdot \mathrm{kg}^{-1}$ in $I$. aquatica to $25.30 \mathrm{mg} \cdot \mathrm{kg}^{-1}$ in $C$. benghalensis. Accumulation of high concentrations of $\mathrm{Pb}$ and $\mathrm{Cd}$ in plant tissues of $C$. benghalensis above normal concentrations of $5 \mathrm{mg} \cdot \mathrm{kg}^{-1} \mathrm{~Pb}$ and $10 \mathrm{mg} \cdot \mathrm{kg}^{-1} \mathrm{Cd}$ was observed by $\mathrm{Zu}$ et al., [57]. The roots of E. fluctuans exhibited low median $\mathrm{Cr}$ values (2.84 $\left.\mathrm{mg} \cdot \mathrm{kg}^{-1}\right)$ while the highest median value was evident in sedges $\left(57.63 \mathrm{mg} \cdot \mathrm{kg}^{-1}\right)$. Cr concentrations in roots of plants, where it could be detected, far exceeded the phytotoxic concentration of $1.5 \mathrm{mg} \cdot \mathrm{kg}^{-1}$ [24]. The general trend also indicates that the roots accumulated greater elemental concentrations compared to the shoots which seem to indicate that these are absorbed from the sediments rather than from the water. Elemental species can have different bioavailability to macrophytes because of physiological differences with respect to uptake sites and uptake mechanisms [58]. Sediment geochemistry control metal speciation in sediments while plant physiology and genotypic differences control the ability of plants to accumulate plant-available forms of metals [16].

In order to get an idea about the site specific metal uptake ability of individual plant species, the site-wise details for metal concentrations in sediments, shoots and roots of all the plants for $\mathrm{Pb}$ (Table 5), Cd (Table 6) and $\mathrm{Cr}$ (Table 7) have also been presented. The transfer factors and bioaccumulation factors for both shoots and roots have also been provided to understand their accumulation potential. It can be seen from the tables that the extent of accumulation of heavy metals by individual plants differed not only with the type of metal but also with the site of study. 
Table 4. Range and median values of Lead, Cadmium and Chromium in shoot and root of different plants pooled over sites.

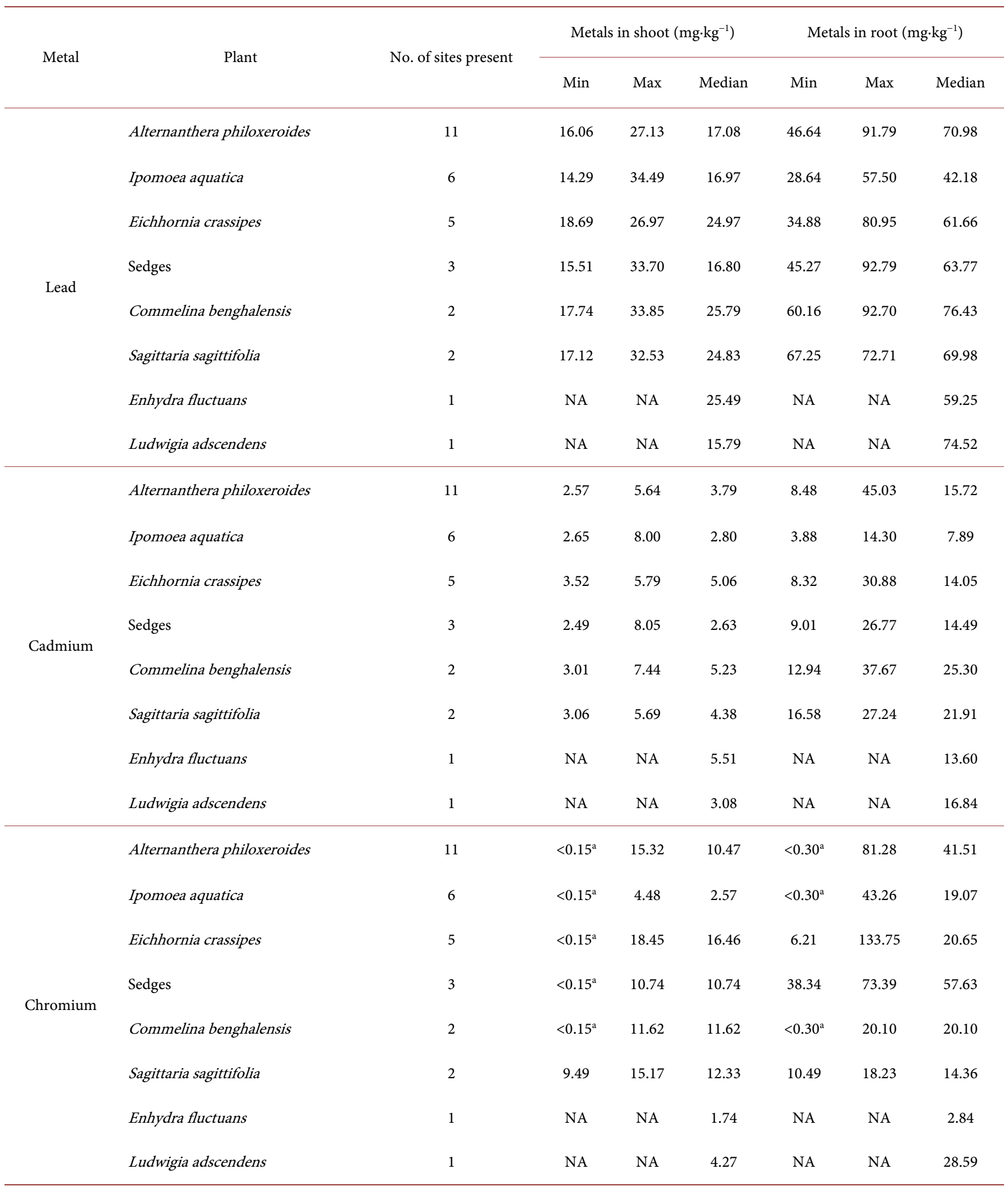

${ }^{a}$ Values below detection limit. NA: not applicable. 
Table 5. Lead concentration in plants across 11 sites.

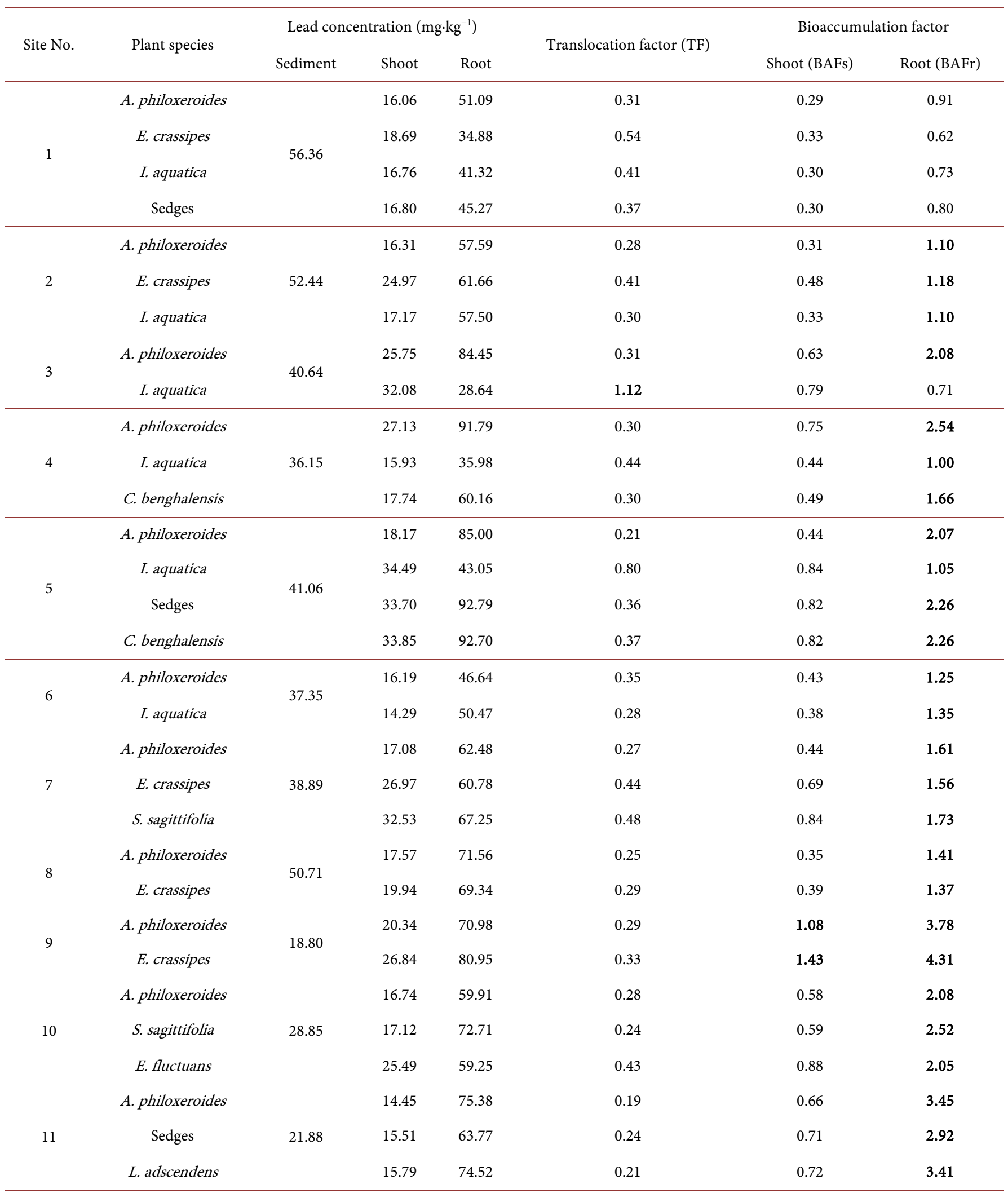

Bold values indicate values $>1$ for (TF) and (BAF). 
Table 6. Cadmium concentration in plants across 11 sites.

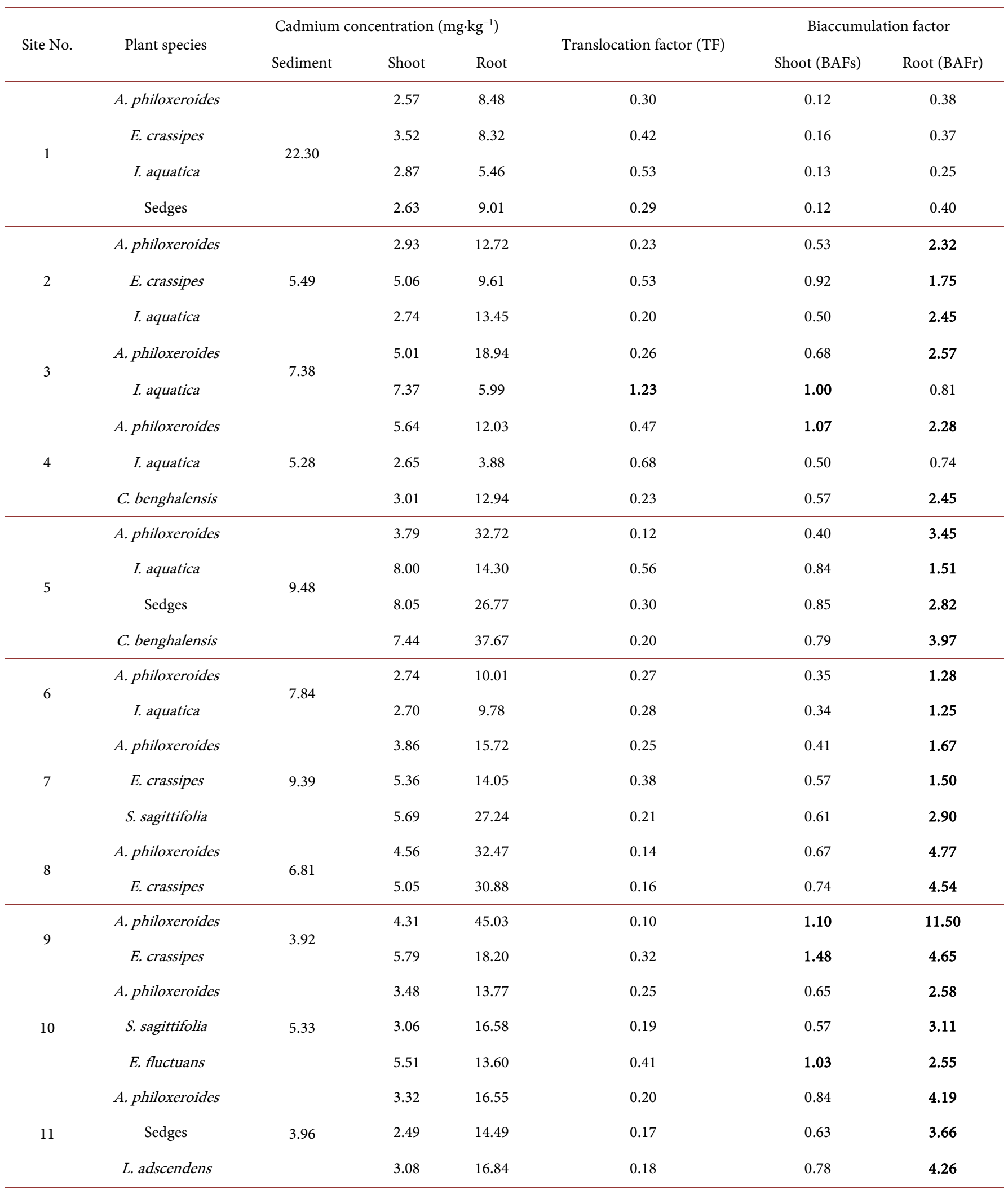

Bold values indicate values $>1$ for $(\mathrm{TF})$ and $(\mathrm{BAF})$. 
Table 7. Chromium concentration in plants across 11 sites.

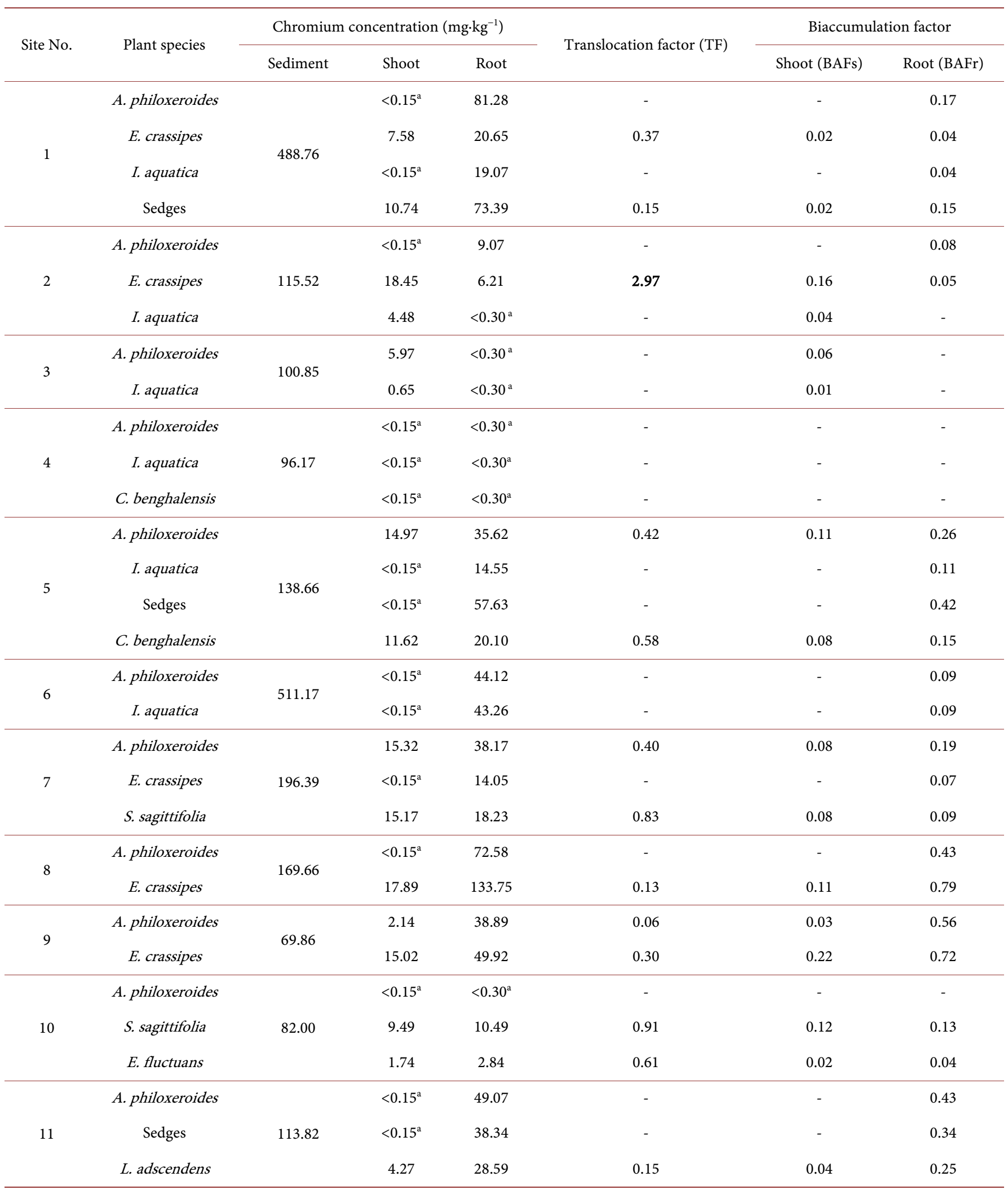

${ }^{\mathrm{a}}$ Values below detection limit. Bold values indicate values $>1$ for $(\mathrm{TF})$. 
The shoot DM values were higher for most plants growing naturally (excepting $E$. crassipes and E. flutuans) when compared to an earlier study which was conducted in less contaminated sites [59]. The dry matter trends observed in this study could simply be indicative of plant maturation since tissue fiber content is positively related to dry matter content [60]. Although a decrease in dry matter content of both shoot and root has been observed in many higher plants as a result of heavy metal toxicity [61], no such relationship between dry matter $\%$ of root or shoot of plants and uptake of $\mathrm{Pb}, \mathrm{Cd}$ or Cr was observed in this study.

\subsubsection{Lead ( $\mathrm{Pb})$}

$\mathrm{Pb}$ exhibits long residence time, is sparingly soluble as a result of rapid conversion to $\mathrm{PbSO}_{4}$ at the soil surface and forms relatively stable organo-metal complexes or chelates with organic matter in soil making it the least phytoavailable amongst all toxic heavy metals. Only $1 \%$ of the total $\mathrm{Pb}$ in soil is water soluble and exchangeable for uptake by plants [62] and its extraction is limited by solubility and diffusion through root surface [63].

Shoot concentration of $\mathrm{Pb}$ for all plants (Table 5) were above the normal levels (5 $10 \mathrm{mg} \cdot \mathrm{kg}^{-1}$ ) suggested for plants, though most of them were below the toxic (30 to 300 $\mathrm{mg} \cdot \mathrm{kg}^{-1}$ ) or critical limits [64]. $\mathrm{Pb}$ concentrations in shoots of the invasive species, $A$. philoxeroides and E. crassipes, did not exceed the critical levels at any site although their roots exhibited $>80 \mathrm{mg} \cdot \mathrm{kg}^{-1} \mathrm{~Pb}$ concentrations at some of the sites. Much higher concentrations of $\mathrm{Pb}\left(>100 \mathrm{mg} \cdot \mathrm{kg}^{-1}\right)$ in shoots of $A$. philoxeroides have been reported from field studies [65] [66]. Higher root $\mathrm{Pb}$ concentrations in E. crassipes (145 to 1110 $\mu \mathrm{g} \cdot \mathrm{g}^{-1}$ ) have also been recorded in a wetland receiving urban run-off [67]. Bioaccumuation of $\mathrm{Pb}$ in shoots (BAFs $>1$ ) was evident only in Site 9, where only A. philoxeroides and $E$. crassipes were present. None of the other plants including the two invasive plants could accumulate $\mathrm{Pb}$ in its shoots.

In some of the sites, native species like I. aquatica, C. benghalensis, S. sagittifolia and the sedges exhibited high shoot $\mathrm{Pb}$ concentrations which were above critical values $(>30$ $\left.\mathrm{mg} \cdot \mathrm{kg}^{-1}\right)$. Of the four plants present in Site 5, which was near an iron industry, three native species had greater than critical shoot $\mathrm{Pb}$ concentrations. Steel and iron manufacturing industries are a potential source of $\mathrm{Pb}$ [68] and the soil, sediments, surface and runoff water of an industrial area were also found to be contaminated with $\mathrm{Pb}$ metal pollution [69]. Root $\mathrm{Pb}$ content was also the highest $\left(>90 \mathrm{mg} \cdot \mathrm{kg}^{-1}\right)$ in C. benghalensis and the sedges. The only invasive plant at this site, A. philoxeroides, had $85 \mathrm{mg} \cdot \mathrm{kg}^{-1}$ of $\mathrm{Pb}$ in its roots with very low shoot $\mathrm{Pb}$ content was very low $\left(18.17 \mathrm{mg} \cdot \mathrm{kg}^{-1}\right)$. The exclusion of metals from aboveground tissues of this plant indicates the low mobilization of heavy metals from roots to the shoots, which has been suggested to be a metal tolerant strategy [70].

Except for all plants in Site 1 and I. aquatica in Site 3, all plants indicated high accumulation potential of $\mathrm{Pb}$ in roots $(\mathrm{BAFr}>1)$, while in plants present in Sites 9 to 11 (with lowest sediment $\mathrm{Pb}$ contents) the bioaccumulation factors in roots were close to $\geq 3$. From the translocation factors in Table $5, I$. aquatica was the only native plant with 
$\mathrm{TF}>1$ implying efficient translocation of $\mathrm{Pb}$ from root to shoot, which is one of the criterion for "hyperaccumulators".

\subsubsection{Cadmium (Cd)}

$\mathrm{Cd}$ enters aquatic systems as effluents mainly through electroplating, pigments, plastic stabilizers and batteries [71] and much of it accumulates in sediments where it presents a risk to benthic biota. The $\mathrm{Cd}$ ion is the most bioavailable to aquatic biota and factors affecting availability include salinity, dissolved organic matter and $\mathrm{pH}$ which affect the chemical forms of $\mathrm{Cd}$ [72]. Cd bioavailability is also dependent on physiological attributes of roots, plant age and genetics of plant species [73].

The sedges exhibited minimum and maximum shoot Cd levels of $2.49 \mathrm{mg} \cdot \mathrm{kg}^{-1}$ in Site 11 and $8.05 \mathrm{mg} \cdot \mathrm{kg}^{-1}$ in Site 5 respectively (Table 6). Although normal Cd levels are generally low in most plant species, shoot concentrations of $\mathrm{Cd}$ for all plants were above the normal levels $\left(0.05-0.2 \mathrm{mg} \cdot \mathrm{kg}^{-1}\right)$. Cd levels in shoots of most species in Sites 3 and 5 were above the critical or toxic ( 5 to $30 \mathrm{mg} \cdot \mathrm{kg}^{-1}$ ) limits suggested for plants [64]. While Site 3 was a construction site near a major road, Site 5 was also located on a major highway where vehicular emissions from fuel consumption, engine oil consumption, tire wear, brake wear, and road abrasion are the most likely sources of $\mathrm{Cd}$ and $\mathrm{Pb}$ [74] [75]. The only plant that could uptake critical concentration of $\mathrm{Cd}\left(>5 \mathrm{mg} \cdot \mathrm{kg}^{-1}\right)$ in its shoots from different sites was $E$. crassipes. Although it could not bioaccumulate significant amounts in its shoots at any site, the potential of E. crassipes for phytoremediation of Cd has been reported [76] [77]. The sites where at least one plant showed high bioaccumulation in shoots (BAFs $>1$ ) were Site 3 ( $I$. aquatica), Site 4 ( $A$. philoxeroides) and Site 10 (E. fluctuans). Moreover, I. aquatica exhibited transfer factors $>1$ for both $\mathrm{Pb}$ and $\mathrm{Cd}$ at Site 3 .

Of concern is the transfer factor of 1.23 in I. aquatica and high bioaccumulation of $\mathrm{Cd}$ in shoots of both $I$. aquatica and E. fluctuans. The leaves and stems of $I$. aquatica (water spinach) and the young shoots of E. fluctuans (water cress or marsh herb) are commonly used as green leafy vegetables in Southeast Asia, India and China [78]-[80]. Both plants have a high food value and is a good source of $\beta$-carotenes and minerals [81] [82]. The value of Cd in the shoots of Enhydra fluctuans (5.51 mg. $\mathrm{kg}^{-1}$ ) in Site 10, the only site where it was present, were above toxic limits which is a source of concern since the plant has reported medicinal values also [83]. The presence of $\mathrm{Cd}$ in shoots of edible plants could be a problem, since a significantly high half-life, faster absorption and low rate of excretion promotes the bioaccumulation of $\mathrm{Cd}$ above toxic level in humans within a short span of time [84].

Most of the plants in the study sites also showed a high bioaccumulation for $\mathrm{Cd}$ in their roots (BAFr > 1), except in Site 1 where none of the plants present could accumulate the element. Site 1 also had the with the highest sediment concentration among sites. In Site 9, A. philoxeroides exhibited exceedingly high accumulation of $\mathrm{Cd}$ in its roots (BAFr 11.5) compared to E. crassipes (BAFr 4.65) while its accumulation in shoots (BAFs 1.10) was less than that of E. crassipes (BAFs = 1.48), thereby showing its potential to limit transfer of $\mathrm{Cd}$ to its above ground tissues. Moreover, it appears that 
the two invasive plants present in Site 9 bioaccumulated large amounts of $\mathrm{Pb}$ and $\mathrm{Cd}$ in their shoots $(\mathrm{BAF}>1)$ as well as in roots $(\mathrm{BAF} \geq 4)$. The production of organic acids by fungi and bacteria present in sewage, which was a constituent of Site 9, promotes solubilization, mobility and bioavailability of metals in sediments by lowering $\mathrm{pH}$ through the process of nitrification and microbial carbon dioxide production [85]-[87]. Considering the fact that this site had low $\mathrm{Pb}$ and $\mathrm{Cd}$ sediment concentrations, the complete absence of native plants in Site 9 could possibly be due to the effect of root exudates secreted from these plants and their toxic effects. An alternative hypothesis proposes that elemental hyperaccumulation in soil may serve an allelopathic function [88] [89]. Some tests have demonstrated defense by hyperaccumulated As, Cd, Ni, Se and Zn, but relatively few plant taxa and natural enemies have been investigated [90].

\subsubsection{Chromium (Cr)}

$\mathrm{Cr}$ occurs in several oxidation states with trivalent and hexavalent states being the most stable. Hexavalent $\mathrm{Cr}\left(\mathrm{Cr}^{6+}\right)$ is the principal species in surface waters and aerobic soils and has a long residence time and is very mobile [91]. Effluents discharged from electroplating, leather tanning, and textile industries release large amounts of $\mathrm{Cr}$ to surface waters [92] [93] which ultimately gets deposited in the sediment.

Despite higher than background levels of $\mathrm{Cr}$ in sediments at most sites, it is evident from Table 7 that it was largely unavailable to some plants in most sites (being below detection limits) probably since $\left(\mathrm{Cr}^{3+}\right)$ binds to negatively charged particles especially clay and organic matter [94]. Shoot Cr concentrations were below detection limit for $I$. aquatica in 4 out of 6 sites and for the invasive A. philoxeroides in 7 out of 11 sites. Substantial accumulation of $\mathrm{Cr}$ in $I$. aquatica from polluted waters has been previously reported [95] [96], however this was not evident from our study. The highest uptake by I. aquatica shoots $\left(4.48 \mathrm{mg} \cdot \mathrm{kg}^{-1}\right)$ in Site 2 was below toxic concentration for plants.

For most other plants, shoot concentration of $\mathrm{Cr}$ was above the normal levels ( 0.1 to $0.5 \mathrm{mg} \cdot \mathrm{kg}^{-1}$ ) suggested for plants [64]. Some even had $\mathrm{Cr}$ values above toxic (5 to 30 $\mathrm{mg} \cdot \mathrm{kg}^{-1}$ ) or critical limits e.g., shoot of the invasive E. crassipes (7.58 to $18.45 \mathrm{mg} \cdot \mathrm{kg}^{-1}$, except Site 7 where it was below detection levels) and those of $S$. sagittifolia (9.49 to $15.17 \mathrm{~m} \mathrm{mg} \cdot \mathrm{kg}^{-1}$ ) among the natives. However, none of the plants could accumulate $\mathrm{Cr}$ in either roots or shoots (BAFr and BAFs $<1$ ). Accumulation of $\mathrm{Cr}$ in roots of plants was much higher compared to their shoots. Maximum $\mathrm{Cr}$ values were noted in the roots of E. crassipes (133.75 $\mathrm{mg} \cdot \mathrm{kg}^{-1}$ ) and the native sedges $\left(73.4 \mathrm{mg} \cdot \mathrm{kg}^{-1}\right)$ at Site 1 , which incidentally had the highest sediment $\mathrm{Cr}$ content of $488.8 \mathrm{mg} \cdot \mathrm{kg}^{-1}$. Domestic waste water effluents, a major Cr source in aquatic ecosystems [97], was the major source of contaminants in Site 2 (with $115.5 \mathrm{ppm}$ sediment $\mathrm{Cr}$ values) where E. crassipes appears to be the only species that could be regarded as an "accumulator species" with a translocation factor $>1(\mathrm{TF}=2.97)$. The roots of $E$. crassipes show promise as a $\mathrm{Cr}$ accumulating plant [98] [99] and have also been used in China for removal of $\mathrm{Cr}^{6+}$ [100]. Sagitaria sagitifolia, another native emergent plant, had elevated levels (though not $>1$ ) of $\mathrm{Cr}$ at both sites of occurrence (translocation factors of 0.8 in Site 7 and 0.9 in Site 10) and could be considered as "accumulators". For hyperaccumulation, plants 
should be able to accumulate concentrations of metals above the threshold concentration or the natural capacity of plants to concentrate metals in their above ground parts which is $>100 \mathrm{mg} \cdot \mathrm{kg}^{-1}$ for $\mathrm{Cd}$ and $>1000 \mathrm{mg} \cdot \mathrm{kg}^{-1}$ for $\mathrm{Pb}$ and $\mathrm{Cr}$ [101]. Since the concentrations of both $\mathrm{Pb}$ and $\mathrm{Cd}$ in I. aquatica and that of $\mathrm{Cr}$ in E. crassipes were far below the natural capacity of plants for metal accumulation, they do not satisfy the "hyperaccumulator" criterion.

Efficient translocation of elements from roots to shoots in plants was not evident from this study as has been reported for wetland plants which only depend on metal exclusion for their metal tolerance due to reduced translocation [22]. However, since the metal uptake by the three most commonly occurring species in the study sites, namely Alternanthera philoxeroides, Eichhornia crassipes and Ipomoea aquatica, were mostly tissue (root) specific [102], it was thought worthwhile to compare their ability to translocate the accumulated metals from their roots to their shoots. The transfer factors for the three plants have been separately shown for $\mathrm{Pb}$ (Figure 2(a)), Cd (Figure 2(b)) and $\mathrm{Cr}$ (Figure 2(c)) and it is clearly evident from the figures that $A$. philoxeroides was not a potential accumulator of any of the three metals ( $\mathrm{TF}<1$ for all metals in all sites), unlike E. crassipes for $\mathrm{Cr}(\mathrm{TF}=2.97)$ in Site 2 and $I$. aquatica for both $\mathrm{Pb}(\mathrm{TF}=1.12)$ and $\mathrm{Cd}(\mathrm{TF}=1.23)$ in Site 3. Infact, $A$. philoxeroides exhibited considerably low translocation potential for all the three toxic elements in most sites as compared to the other two plants indicating that the metals have been sequestered in the roots. High accumulation of heavy metals in roots and low translocation in shoots may indicate appropriateness of a plant species for phytostabilisation [7] [103]. This mechanism of partitioning is a common strategy of plants to concentrate harmful ions in the roots in order to prevent toxicity to the leaves which is the site of photosynthesis and other metabolic activities [104] thereby reducing metal bioavailability for entry into the food chain. This strategy could prove to be beneficial for A. philoxeroides, the twigs and shoots of which are cooked and consumed as a vegetable in many parts of India [105]-[107].

\section{Conclusion}

In urban areas where heavy metal pollution of freshwater ecosystems is constantly on the rise, this study highlights the ability of some emergent rooted plants to phytostabilize contaminants in the sediments by accumulation in roots thereby reducing the risk to human health and the environment. Both invasive as well as some native plants were equally capable of accumulating $\mathrm{Pb}$ and $\mathrm{Cd}$ into their roots. However with regard to the widespread consumption and distribution of $I$. aquatica across large parts of the Asian sub-continent, this native species needs to be carefully monitored due to its ability to accumulate $\mathrm{Pb}$ and $\mathrm{Cd}$ in its above ground parts without any obvious visible symptoms. On the other hand, A. philoxeroides, being a cosmopolitan species shows considerable promise not only as an efficient accumulator of $\mathrm{Pb}$ and $\mathrm{Cd}$ in its roots but its ability to rapidly uptake heavy metals even at very low ambient levels could also make it an efficient indicator of the aquatic ecosystem quality. Moreover, due to its restricted transfer of metals to its above ground parts, the plant can additionally be promoted for feed/ 

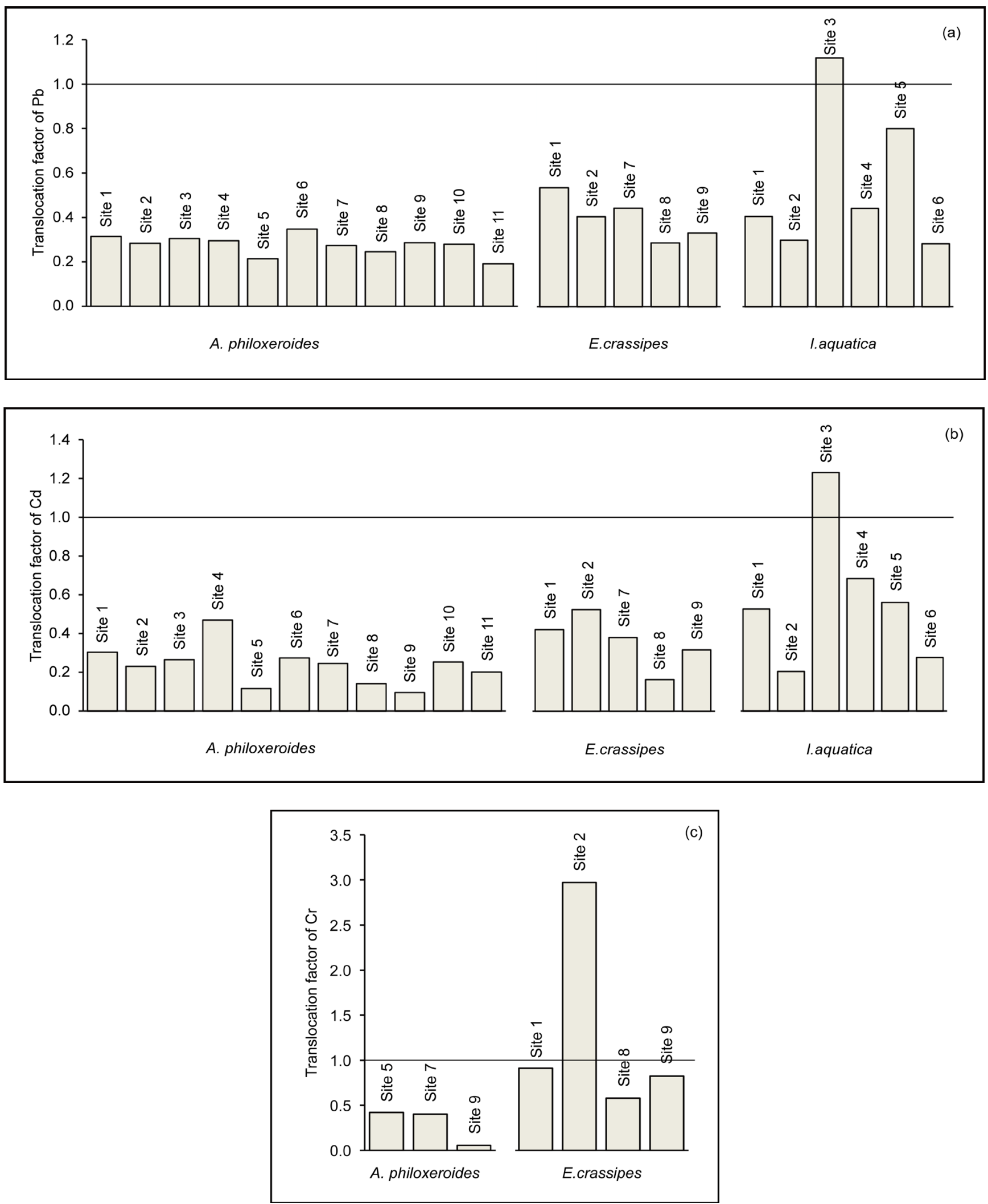

Figure 2. Translocation factor of Lead (a), Cadmium (b) in A.philoxeroides, E. crassipes and I. aquatica and Chromium (c) in A. philoxeroides and $E$. crassipes. The horizontal line indicates effective translocation of element from roots to shoots. 
food use. Repeated harvesting of $A$. philoxeroides plant parts from water bodies would doubly contribute to its use as well as restrict its spread potential, a negative aspect of all invasive plants. The potential of $A$. philoxeroides as a metal excluder needs to be explored since it translocates less to its shoots as compared to E. crassipes and I. aquatica.

\section{Acknowledgements}

This project was supported financially by the Indian Statistical Institute, Kolkata. We would like to acknowledge Sandip Chatterjee, Susant Mahankur and Jahira Begam for technical and field assistance. We would like to thank the anonymous Reviewers' for their helpful suggestions.

\section{References}

[1] Nyangababo, J.T., Henry, E. and Omutange, E. (2005) Lead, Cadmium, Copper, Manganese and Zinc in Wetland Waters of Victoria Lake Basin, East Africa. Bulletin of Environmental Contamination and Toxicology, 74, 1003-1010. http://dx.doi.org/10.1007/s00128-005-0679-y

[2] Sekabira, K., Origa, H.O., Basamba, T.A., Mutumba, G. and Kakudidi, E. (2010) Assessment of Heavy Metal Pollution in the Urban Stream Sediments and Its Tributaries. International Journal of Environmental Science and Technology, 7, 435-446.

http://dx.doi.org/10.1007/BF03326153

[3] Singh, M., Ansari, A., Müller, G. and Singh, I. (1997) Heavy Metals in Freshly Deposited Sediments of the Gomati River (A Tributary of the Ganga River): Effects of Human Activities. Environmental Geology, 29, 246-252. http://dx.doi.org/10.1007/s002540050123

[4] Lal, N. (2010) Molecular Mechanisms and Genetic Basis of Heavy Metal Toxicity and Tolerance in Plants. In: Ashraf, M., Ozturk, M. and Ahmad, M.S.A., Eds., Plant Adaptation and Phytoremediation, Springer, New York, 35-58.

http://dx.doi.org/10.1007/978-90-481-9370-7_2

[5] Dhir, B. (2013) Introduction. In: Dhir, B., Ed., Phytoremediation: Role of Aquatic Plants in Environmental Clean- $U$, Springer India, New Delhi, 1-20. http://dx.doi.org/10.1007/978-81-322-1307-9_1

[6] Forstner, U. and Wittman, G. (2012) Metal Pollution in the Aquatic Environment. 2nd Edition, Springer-Verlag, Berlin.

[7] Malik, R.N., Husein, S.Z. and Nazir, I. (2010) Heavy Metal Contamination and Accumulation in Soil and Wild Plants Species from Industrial Area of Islamabad Pakistan. Pakistan Journal of Botany, 42, 291-301.

[8] Revenga, C., Campbell, I., Abell, R., De Villiers, P. and Bryer, M. (2005) Prospects for Monitoring Freshwater Ecosystems towards the 2010 Targets. Philosophical Transactions of the Royal Society of London B: Biological Sciences, 360, 397-413. http://dx.doi.org/10.1098/rstb.2004.1595

[9] Dudgeon, D., Arthington, A.H., Gessner, M.O., Kawabata, Z.I., Knowler, D.J., Leveque, C., Naiman, R.J., Prieur-Richard, A.H., Soto, D., Stiassny, M.L.J. and Sullivan, C.A. (2006) Freshwater Biodiversity: Importance, Threats, Status and Conservation Challenges. Biological Reviews, 81, 163-182. http://dx.doi.org/10.1017/S1464793105006950

[10] Jenssen, P., Maehlum, T. and Krogstad, T. (1993) Potential Use of Constructed Wetlands for Wastewater Treatment in Northern Environments. Water Science and Technology, 28, 149-157. 
[11] Zedler, J.B. and Kercher, S. (2004) Causes and Consequences of Invasive Plants in Wetlands: Opportunities, Opportunists, and Outcomes. Critical Reviews in Plant Sciences, 23, 431-452. http://dx.doi.org/10.1080/07352680490514673

[12] Havel, J.E., Kovalenko, K.E., Thomaz, S.M., Amalfitano, S. and Kats, L.B. (2015) Aquatic Invasive Species: Challenges for the Future. Hydrobiologia, 750, 147-170. http://dx.doi.org/10.1007/s10750-014-2166-0

[13] Sushilkumar (2011) Aquatic Weeds Problems and Management in India. Indian Journal of Weed Science, 43, 118-138.

[14] Hua, J., Zhang, C., Yin, Y., Chen, R. and Wang, X. (2012) Phytoremediation Potential of Three Aquatic Macrophytes in Manganese-Contaminated Water. Water and Environment Journal, 26, 335-342. http://dx.doi.org/10.1111/j.1747-6593.2011.00293.x

[15] Outridge, P.M. and Noller, B.N. (1991) Accumulation of Toxic Trace Elements by Freshwater Vascular Plants. Reviews of Environmental Contamination and Toxicology, 121, 163. http://dx.doi.org/10.1007/978-1-4612-3196-7_1

[16] Brook, R.R. and Robinson, B.H. (1998) Aquatic Phytoremediation by Accumulator Plants. In: Brook, R.R., Ed., Plants that Hyperaccumulate Heavy Metals. Their Role in Phytoremediation, Microbiology, Archaeology, Mineral Exploration and Phytomining, CABI International, Wallingford, 203-226.

[17] Rai, P.K. (2009) Heavy Metal Phytoremediation from Aquatic Ecosystems with Special Reference to Macrophytes. Critical Reviews in Environmental Science and Technology, 39, 697-753. http://dx.doi.org/10.1080/10643380801910058

[18] Sinha, S., Saxena, R. and Singh, S. (2002) Comparative Studies on Accumulation of Cr from Metal Solution and Tannery Effluent under Repeated Metal Exposure by Aquatic Plants: Its Toxic Effects. Environmental Monitoring and Assessment, 80, 17-31. http://dx.doi.org/10.1023/A:1020357427074

[19] Rai, P.K. (2008) Technical Note: Phytoremediation of Hg and Cd from Industrial Effluents Using an Aquatic Free Floating Macrophyte Azolla pinnata. International Journal of Phytoremediation, 10, 430-439. http://dx.doi.org/10.1080/15226510802100606

[20] Rane, N.R., Chandanshive, V.V., Watharkar, A.D., Khandare, R.V., Patil, T.S., Pawar, P.K. and Govindwar, S.P. (2015) Phytoremediation of Sulfonated Remazol Red Dye and Textile Effluents by Alternanthera philoxeroides: An Anatomical, Enzymatic and Pilot Scale Study. Water Research, 83, 271-281. http://dx.doi.org/10.1016/j.watres.2015.06.046

[21] Cardwell, A.J., Hawker, D.W. and Greenway, M. (2002) Metal Accumulation in Aquatic Macrophytes from Southeast Queensland, Australia. Chemosphere, 48, 653-663. http://dx.doi.org/10.1016/S0045-6535(02)00164-9

[22] Deng, H., Yea, Z.H. and Wong, M.H. (2004) Accumulation of Lead, Zinc, Copper and Cadmium by 12 Wetland Plant Species Thriving in Metal-Contaminated Sites in China. Environmental Pollution, 132, 29-40. http://dx.doi.org/10.1016/j.envpol.2004.03.030

[23] Lokeshwari, H. and Chandrappa, G.T. (2007) Effects of Heavy Metal Contamination from Anthropogenic Sources on Dasarahalli Tank, India. Lakes \& Reservoirs. Research \& Management, 12, 121-128. http://dx.doi.org/10.1111/j.1440-1770.2007.00337.x

[24] Nayek, S., Gupta, S. and Saha, R. (2010) Effects of Metal Stress on Biochemical Response of Some Aquatic Macrophytes Growing along an Industrial Waste Discharge Channel. Journal of Plant Interactions, 5, 91-99. http://dx.doi.org/10.1080/17429140903282904

[25] Núñez, S.R., Negrete, J.M., Rios, J.A., Hadad, H.R. and Maine, M.A. (2011) Hg, Cu, Pb, Cd, and $\mathrm{Zn}$ Accumulation in Macrophytes Growing in Tropical Wetlands. Water, Air, \& Soil Pollution, 216, 361-373. http://dx.doi.org/10.1007/s11270-010-0538-2 
[26] Mazumdar, K. and Das, S. (2015) Phytoremediation of Pb, Zn, Fe, and Mg with 25 Wetland Plant Species from Paper Mill Contaminated Site in North East India. Environmental Science and Pollution Research, 22, 701-710. http://dx.doi.org/10.1007/s11356-014-3377-7

[27] Meitei, M.D. and Prasad, M.N.V. (2016) Bioaccumulation of Nutrients and Metals in Sediment, Water, and Phoomdi from Loktak Lake (Ramsar Site), Northeast India: Phytoremediation Options and Risk Assessment. Environmental Monitoring and Assessment, 188, 117. http://dx.doi.org/10.1007/s10661-016-5339-7

[28] Jackson, L.J. and Kalff, J. (1993) Patterns in Metal Content of Submerged Aquatic Macrophytes: The Role of Plant Growth Form. Freshwater Biology, 29, 351-359. http://dx.doi.org/10.1111/j.1365-2427.1993.tb00769.x

[29] Jackson, L.J., Kalff, J. and Rasmussen, J.B. (1993) Sediment pH and Redox Potential Affect the Bioavailability of $\mathrm{Al}, \mathrm{Cu}, \mathrm{Fe}, \mathrm{Mn}$ and $\mathrm{Zn}$ to Rooted Aquatic Macrophytes. Canadian Journal of Fisheries and Aquatic Sciences, 50, 143-148. http://dx.doi.org/10.1139/f93-016

[30] Greger, M. (2004) Metal Availability, Uptake, Transport and Accumulation in Plants. In: Prasad, M.N.V., Ed., Heavy Metal Stress in Plants from Biomolecules to Ecosystems, 2nd Edition, Springer-Verlag, Berlin, 1-27. http://dx.doi.org/10.1007/978-3-662-07743-6_1

[31] APHA (1998) Standard Methods for the Examination of Water and Wastewater. 20th Edition, American Public Health Association, Washington DC.

[32] AOAC (1990) AOAC Official Methods of Analysis. 15th Edition, Association of Official Analytical Chemists, Arlington.

[33] Chinmayee, M.D., Mahesh, B., Pradesh, S., Mini, I. and Swapna, T. (2012) The Assessment of Phytoremediation Potential of Invasive Weed Amaranthus spinosus L. Applied Biochemistry and Biotechnology, 167, 1550-1559. http://dx.doi.org/10.1007/s12010-012-9657-0

[34] Baker, A.J.M. (1981) Accumulators and Excluders-Strategies in the Response of Plants to Heavy Metals. Journal of Plant Nutrition, 3, 643-654. http://dx.doi.org/10.1007/s12010-012-9657-0

[35] Baker, A.J.M. and Brooks, R.R. (1989) Terrestrial Higher Plants which Hyperaccumulate Metallic Elements. A Review of Their Distribution, Ecology and Phytochemistry. Biorecovery, 1, 81-126. http://dx.doi.org/10.1080/01904168109362867

[36] Malik, A. (2007) Environmental Challenges vis a vis Opportunity: The Case of Water Hyacinth. Environment International, 33, 122-138.

http://dx.doi.org/10.1016/j.envint.2006.08.004

[37] Iftekhar, I. (2009) Fighting with a Weed: Water Hyacinth and the State of Colonial Bengal, c. 1910-1947. Environment and History, 15, 35-59. http://dx.doi.org/10.3197/096734009X404653

[38] Chatterjee, A. and Dewanji, A. (2014) Effect of Varying Alternanthera philoxeroides Cover on the Macrophyte Species Diversity of Pond Ecosystems: A Quadrat-Based Study. Aquatic Invasions, 9, 343-355. http://dx.doi.org/10.3391/ai.2014.9.3.09

[39] Zhao, K.L., Liu, X.M., Xu, J.M. and Selim, H.M. (2010) Heavy Metal Contaminations in a Soil-Rice System: Identification of Spatial Dependence in Relation to Soil Properties of Paddy Fields. Journal of Hazardous Materials, 181, 778-787. http://dx.doi.org/10.1016/j.jhazmat.2010.05.081

[40] Walton, N.R.G. (1989) Electrical Conductivity and Total Dissolved Solids-What Is Their Precise Relationship? Desalination, 72, 275-292. http://dx.doi.org/10.1016/0011-9164(89)80012-8

[41] Atekwana, E.A., Atekwana, E.A., Rowe, R.S., Werkema, D.D. and Legall, F.D. (2004) The Relationship of Total Dissolved Solids Measurements to Bulk Electrical Conductivity in an 
Aquifer Contaminated with Hydrocarbon. Journal of Applied Geophysics, 56, 281-294. http://dx.doi.org/10.1016/S0926-9851(04)00057-6

[42] Hannouche, A., Chebbo, G., Ruban, G., Tassin, B., Lemaire, B.J. and Joannis, C. (2011) Relationship between Turbidity and Total Suspended Solids Concentration within a Combined Sewer System. Water Science and Technology, 64, 2445-2452. http://dx.doi.org/10.2166/wst.2011.779

[43] Chatterjee, S., Chetia, M., Singh, L., Chattopadhyay, B., Datta, S. and Mukhopadhyay, S. (2011) A Study on the Phytoaccumulation of Waste Elements in Wetland Plants of a Ramsar Site in India. Environmental monitoring and assessment, 178, 361-371. http://dx.doi.org/10.1007/s10661-010-1695-x

[44] Adhikari, S., Ghosh, L., Rai, S. and Ayyappan, S. (2009) Metal Concentrations in Water, Sediment, and Fish from Sewage-fed Aquaculture Ponds of Kolkata, India. Environmental Monitoring and Assessment, 159, 217-230. http://dx.doi.org/10.1007/s10661-008-0624-8

[45] Burton Jr., G.A. (2002) Sediment Quality Criteria in Use around the World. Limnology, 3, 65-76. http://dx.doi.org/10.1007/s102010200008

[46] Dunbabin, J.S. and Bowmer, K.H. (1992) Potential Use of Constructed Wetlands for Treatment of Industrial Wastewaters Containing Metals. Science of the Total Environment, 11, 151-168. http://dx.doi.org/10.1016/0048-9697(92)90353-T

[47] Hakanson, L. (1980) An Ecological Risk Index for Aquatic Pollution Control. A Sedimentological Approach. Water Research, 14, 975-1001.

http://dx.doi.org/10.1016/0043-1354(80)90143-8

[48] Sarkar, S., Ghosh, P.B., Sil, A.K. and Saha, T. (2011) Heavy Metal Pollution Assessment through Comparison of Different Indices in Sewage-Fed Fishery Pond Sediments at East Kolkata Wetland, India. Environmental Earth Sciences, 63, 915-924. http://dx.doi.org/10.1007/s12665-010-0760-7

[49] Krishna, A.K. and Govil, P.K. (2004) Heavy Metal Contamination of Soil around Pali Industrial Area, Rajasthan, India. Environmental Geology, 47, 38-44. http://dx.doi.org/10.1007/s00254-004-1124-y

[50] Parth, V., Murthy, N.N. and Saxena, P.R. (2011) Assessment of Heavy Metal Contamination in Soil around Hazardous Waste Disposal Sites in Hyderabad City (India): Natural and Anthropogenic Implications. Journal of Environmental Research and Management, 2, $27-$ 34.

[51] Mwinyihija, M. (2010) Main Pollutants and Environmental Impacts of the Tanning Industry. In: Mwinyihija, M., Ed., Ecotoxicological Diagnosis in the Tanning Industry, Springer, New York, 17-35. http://dx.doi.org/10.1007/978-1-4419-6266-9_2

[52] Apte, A.D., Verma, S., Tare, V. and Bose, P. (2005) Oxidation of Cr (III) in Tannery Sludge to Cr (VI): Field Observations and Theoretical Assessment. Journal of Hazardous Materials, 121, 215-222. http://dx.doi.org/10.1016/j.jhazmat.2005.02.010

[53] Hingston, J., Collins, C., Murphy, R. and Lester, J. (2001) Leaching of Chromated Copper Arsenate Wood Preservatives: A Review. Environmental Pollution, 111, 53-66. http://dx.doi.org/10.1016/S0269-7491(00)00030-0

[54] Markert, B. (1992) Presence and Significance of Naturally Occurring Chemical Elements of the Periodic System in the Plant Organism and Consequences for Future Investigations on Inorganic Environmental Chemistry in Ecosystems. Vegetatio, 103, 1-30.

[55] Pais, J. and Jones, J.B. (1997) The Handbook of Trace Elements. CRC Press, Boca Raton.

[56] Sharma, P. and Dubey, R.S. (2005) Lead Toxicity in Plants. Brazilian Journal of Plant Physiology, 17, 1-19. http://dx.doi.org/10.1590/s1677-04202005000100004 
[57] Zu, Y.Q., Li, Y., Christian, S., Laurent, L. and Lin, F. (2004) Accumulation of Pb, Cu and Zn in Plants and Hyperaccumulator Choice in Lamping Lead-Zinc Mine Area, China. Environmental International, 30, 567-576. http://dx.doi.org/10.1016/j.envint.2003.10.012

[58] Leppard, G.G. (1983) Trace Element Speciation and the Quality of Surface Waters: An Introduction to the Scope for Research. In: Leppard, G.G., Ed., Trace Element Speciation in Surface Waters and Its Ecological Implications, Plenum Press, New York, 1-15. http://dx.doi.org/10.1007/978-1-4684-8234-8_1

[59] Banerjee, A. and Matai, S. (1990) Composition of Indian Aquatic Plants in Relation to Utilization as Animal Forage. Journal of Aquatic Plant Management, 28, 69-73.

[60] Grime, J.P., Cornelissen, J.H.C., Thompson, K. and Hodgson, J.G. (1996) Evidence of a Causal Connection between Antiherbivore Defence and the Decomposition Rate of Leaves. Oikos, 77, 489-494. http://dx.doi.org/10.2307/3545938

[61] Sharma, R.K. and Agrawal, M. (2005) Biological Effects of Heavy Metals: An Overview. Journal of Environmental Biology, 26, 301-313.

[62] Huang, J.W., Chen, J., Berti, W.R. and Cunningham, S.D. (1997) Phytoremediation of Lead-Contaminated Soils: Role of Synthetic Chelates in Lead Phytoextraction. Environmental Science \& Technology, 31, 800-805. http://dx.doi.org/10.1021/es9604828

[63] Cataldo, D.A. and Wildung, R.E. (1978) Soil and Plant Factors Influencing the Accumulation of Heavy Metals by Plants. Environmental Health Perspectives, 27, 149-159. http://dx.doi.org/10.1289/ehp.7827149

[64] Kabata-Pendias, A. and Pendias, H. (2011) Trace Elements in Soils and Plants. 4th Edition, CRC Press, Boca Raton.

[65] Deng, H., Ye, Z. and Wong, M. (2006) Lead and Zinc Accumulation and Tolerance in Populations of Six Wetland Plants. Environmental Pollution, 141, 69-80. http://dx.doi.org/10.1016/j.envpol.2005.08.015

[66] Nan, H., Jifang, Z., Dexin, D., Guangyue, L., Jie, Y., Xin, C. and Jia, Y. (2013) Screening of Native Hyperaccumulators at the Huayuan River Contaminated by Heavy Metals. Bioremediation Journal, 17, 21-29. http://dx.doi.org/10.1080/10889868.2012.703260

[67] Vesk, P.A. and Allaway, W.G. (1997) Spatial Variation of Copper and Lead Concentrations of Water Hyacinth Plants in a Wetland Receiving Urban Run-Off. Aquatic Botany, 59, 3344. http://dx.doi.org/10.1016/S0304-3770(97)00032-6

[68] Nriagu, J.O. and Pacyna, J.M. (1988) Quantitative Assessment of Worldwide Contamination of Air, Water and Soils by Trace Metals. Nature, 333, 134-139. http://dx.doi.org/10.1038/333134a0

[69] Patel, K.S., Ambade, B., Sharma, S., Sahu, D., Jaiswal, N.K., Gupta, S., Dewangan, R.K., Nava, S., Lucarelli, F., Blazhev, B., Stefanova, R. and Hoinkis, J. (2010) Lead Environmental Pollution in Central India. In: Blandna, R., Ed., New Trends in Technologies, InTech, New York, 65-76.

[70] Taylor, G.J. and Crowder, A.A. (1983) Uptake and Accumulation of Heavy Metals by Typha latifolia in Wetlands of the Sudbury, Ontario Region. Canadian Journal of Botany, 61, 63-73. http://dx.doi.org/10.1139/b83-005

[71] Nriagu, J.O. (1980) Production Uses, and Properties of Cadmium. John Wiley \& Sons, New York.

[72] Wright, D.A. and Welbourn, P.M. (1994) Cadmium in the Aquatic Environment: A Review of Ecological, Physiological, and Toxicological Effects on Biota. Environmental Reviews, 2, 187-214. http://dx.doi.org/10.1139/a94-012

[73] Harter, R.D. and Naidu, R. (2001) An Assessment of Environmental and Solution Parame- 
ter Impact on Trace-Metal Sorption by Soils. Soil Science Society of America Journal, 65, 597-612. http://dx.doi.org/10.2136/sssaj2001.653597x

[74] Wilcke, W., Silke, M., Nualsri, K. and Wolfgang, Z. (1998) Urban Soil Contamination in Bangkok: Heavy Metal and Aluminium Partitioning in Topsoils. Geoderma, 86, 211-228. http://dx.doi.org/10.1016/S0016-7061(98)00045-7

[75] Kiem, S. (2002) Heavy Metal Pollution of Waterways from Road Runoff. Unpublished Bachelor Degree Thesis, School of Engineering, James Cook University, Townsville.

[76] Agunbiade, F.O., OluOwolabi, B.I. and Adebowale, K.O. (2009) Phytoremediation Potential of Eichhornia crassipes in Metal Contaminated Coastal Water. Bioresource Technology, 100, 4521-4526. http://dx.doi.org/10.1016/j.biortech.2009.04.011

[77] Das, S., Goswami, S. and Talukdar, D.A. (2016) Physiological Responses of Water Hyacinth, Eichhornia crassipes (Mart.) Solms, to Cadmium and Its Phytoremediation Potential. Turkish Journal of Biology, 40, 84-94. http://dx.doi.org/10.3906/biy-1411-86

[78] Edie, H. and Ho, B. (1969) Ipomoea aquatica as a Vegetable Crop in Hong Kong. Economic Botany, 23, 32-36. http://dx.doi.org/10.1007/BF02862969

[79] Sengupta, S.R. and Pal, B. (1970) Composition of Edible Wild Greens. Journal of the Science of Food and Agriculture, 21, 215. http://dx.doi.org/10.1002/jsfa.2740210412

[80] Barua, U., Hore, D.K. and Sarma, R. (2007) Wild Edible Plants of Majuli Island and Darrang Districts of Assam. Indian Journal of Traditional Knowledge, 6, 191-194.

[81] National Academy of Sciences (1976) Aquatic Plants for Food, Miscellaneous Uses. In: Making Aquatic Weeds Useful: Some Perspectives for Developing Countries, National Academy of Sciences, Washington DC, 127-147.

[82] Dewanji, A., Matai, S., Si, L., Barik, S. and Nag, A. (1993) Chemical Composition of Two Semi-Aquatic Plants for Food Use. Plant Foods for Human Nutrition, 44, 11-16. http://dx.doi.org/10.1007/BF01088478

[83] Rahman, M.T., Begum, N., Alimuzzaman, M. and Khan, M.O.F. (2002) Analgesic Activity of Enhydra fluctuans. Fitoterapia, 73, 77-79. http://dx.doi.org/10.1016/S0367-326X(02)00212-5

[84] Jarup, L., Berglund, M., Elinder, C.G., Nordberg, G. and Vahter, M. (1998) Health Effects of Cadmium-A Review of the Literature and a Risk Estimate. Scandinavian Journal of Work, Environment \& Health, 24, 1-51.

[85] Smith, S.R. (1995) Agricultural Recycling of Sewage Sludge and the Environment. CAB International, Wallingford.

[86] Nautiyal, C.S., Bhadauria, S., Kumar, P., Lal, H. and Verma, M.D. (2000) Stress Induced Phosphate Solubilization in Bacteria Isolated from Alkaline Soils. FEMS Microbiology Letters, 182, 291-296. http://dx.doi.org/10.1111/j.1574-6968.2000.tb08910.x

[87] Siokwu, S. and Anyanwn, C.U. (2012) Tolerance for Heavy Metals by Filamentous Fungi Isolated from a Sewage Oxidation Pond. African Journal of Microbiology Research, 6, 20382043. http://dx.doi.org/10.5897/AJMR11.1258

[88] Morris, C., Grossl, P.R. and Call, C.A. (2009) Elemental Allelopathy: Processes, Progress, and Pitfalls. Plant Ecology, 202, 1-11. http://dx.doi.org/10.1007/s11258-008-9470-6

[89] El Mehdawi, A.F., Quinn, C.F. and Pilon-Smits, E.A.H. (2011) Effects of Selenium Hyperaccumulation on Plant-Plant Interactions: Evidence for Elemental Allelopathy? New Phytologist, 191, 120-131. http://dx.doi.org/10.1111/j.1469-8137.2011.03670.x

[90] Boyd, R.S. (2007) The Defense Hypothesis of Elemental Hyperaccumulation: Status, Challenges and New Directions. Plant and Soil, 293, 153-176. 
http://dx.doi.org/10.1007/s11104-007-9240-6

[91] Nriagu, J.O. and Nieboer, E. (1988) Chromium in the Natural and Human Environments. Vol. 20, John Wiley \& Sons, New York.

[92] Avudainayagam, S., Megharaj, M., Owens, G., Kookana, R.S., Chittleborough, D. and Naidu, R. (2003) Chemistry of Chromium in Soils with Emphasis on Tannery Waste Sites. Reviews of Environmental Contamination and Toxicology, 178, 53-91. http://dx.doi.org/10.1007/0-387-21728-2_3

[93] Johnson, J., Schewel, L. and Graedel, T.E. (2006) The Contemporary Anthropogenic Chromium Cycle. Environmental Science \& Technology, 40, 7060-7069. http://dx.doi.org/10.1021/es060061i

[94] Banks, M.K., Schwab, A.P. and Henderson, C. (2006) Leaching and Reduction of Chromium in Soil as Affected by Soil Organic Content and Plants. Chemosphere, 62, 255-264. http://dx.doi.org/10.1016/j.chemosphere.2005.05.020

[95] Chandra, P., Tripathi, R.D., Rai, U.N., Sinha, S. and Garg, P. (1993) Biomonitoring and Amelioration of Nonpoint Source Pollution in Some Aquatic Bodies. Water Science \& Technology, 28, 323-326.

[96] Rai, U.N., Sinha, S. and Chandra, P. (1996) Metal Biomonitoring in Water Resources of Eastern Ghats, Koraput (Orissa), India by Aquatic Plants. Environmental Monitoring and Assessment, 43, 125-137. http://dx.doi.org/10.1007/BF00398603

[97] Barceloux, D.G. (1999) Chromium. Clinical Toxicology, 37, 173-194. http://dx.doi.org/10.1081/clt-100102418

[98] Jana, S. (1988) Accumulation of $\mathrm{Hg}$ and $\mathrm{Cr}$ by Three Aquatic Species and Subsequent Changes in Several Physiological and Biochemical Plant Parameter. Water, Air, and Soil Pollution, 38, 105-109.

[99] Mishra, V.K. and Tripathi, B.D. (2008) Concurrent Removal and Accumulation of Heavy Metals by the Three Aquatic Macrophytes. Bioresource Technology, 99, 7091-7097. http://dx.doi.org/10.1016/j.biortech.2008.01.002

[100] Prakash, C.P. and Kulshreshtha, K. (2004) Chromium Accumulation and Toxicity in Aquatic Vascular Plants. The Botanical Review, 70, 313-327. http://dx.doi.org/10.1663/0006-8101(2004)070[0313:CAATIA]2.0.CO;2

[101] Baker, A.J.M., McGrath, S.P., Reeves, R.D. and Smith, J.A.C. (2000) Metal Hyperaccumulator Plants: A Review of the Ecology and Physiology of a Biological Resource for Phytoremediation of Metal-Polluted Soils. In: Terry, N. and Banuelos, G., Eds., Phytoremediation of Contaminated Soil and Water, Lewis Publishers, London, 85-107.

[102] Vardanyan, L.G. and Ingole, B.S. (2006) Studies on Heavy Metal Accumulation in Aquatic Macrophytes from Sevan (Armenia) and Carambolim (India) Lake Systems. Environment International, 11, 208-218. http://dx.doi.org/10.1016/j.envint.2005.08.013

[103] Archer, M.J.G. and Caiwell, R.A. (2004) Response of Six Australian Plants Species to Heavy Metal Contamination at an Abandoned Mine Site. Water, Air, and Soil Pollution, 157, $257-$ 267. http://dx.doi.org/10.1023/B:WATE.0000038900.66771.bf

[104] Qian, J.-H., Zayed, A., Zhu, Y.L., Yu, M. and Terry, N. (1999) Phytoaccumulation of Trace Elements by Wetland Plants. III. Uptake and Accumulation of Ten Trace Elements by Twelve Plant Species. Journal of Environment Quality, 28, 1448-1455. http://dx.doi.org/10.2134/jeq1999.00472425002800050009x

[105] Agrahar-Murugkar, D. and Pal, P.P. (2004) Intake of Nutrients and Food Sources of Nutrients among the Khasi Tribal Women of India. Nutrition, 20, 268-273. http://dx.doi.org/10.1016/j.nut.2003.11.008 
[106] Sen, S., Chakraborty, R., De, B. and Devanna, N. (2011) An Ethnobotanical Survey of Medicinal Plants Used by Ethnic People in West and South District of Tripura, India. Journal of Forestry Research, 22, 417-426. http://dx.doi.org/10.1007/s11676-011-0184-6

[107] Amalraj, A. and Pius, A. (2015) Bioavailability of Calcium and Its Absorption Inhibitors in Raw and Cooked Green Leafy Vegetables Commonly Consumed in India-An In Vitro Study. Food Chemistry, 170, 430-436. http://dx.doi.org/10.1016/j.foodchem.2014.08.031

Submit or recommend next manuscript to SCIRP and we will provide best service for you:

Accepting pre-submission inquiries through Email, Facebook, LinkedIn, Twitter, etc. A wide selection of journals (inclusive of 9 subjects, more than 200 journals)

Providing 24-hour high-quality service

User-friendly online submission system

Fair and swift peer-review system

Efficient typesetting and proofreading procedure

Display of the result of downloads and visits, as well as the number of cited articles

Maximum dissemination of your research work

Submit your manuscript at: http://papersubmission.scirp.org/

Or contact ajps@scirp.org 